Jurnal OFFSHORE, Volume 1 No. 2 Desember 2017 : 39 - 47 ; e -ISSN : 2549-8681

\title{
PENGELOLAAN DAN PROSES INSTALASI PERAWATAN AIR LIMBAH DALAM PEMBERSIHAN MINYAK DAN GAS DENGAN MENGGUNAKAN SEPARATOR DAN SCRUBBER DI LAPANGAN "X"
}

\author{
Zainal Imron Hidayat ${ }^{1)}$ \\ ${ }^{1)}$ Envirosains Konsultan (CV. Dunia Baru Indonesia) \\ Corresponding author, email : zainalimronhidayat@gmail.com
}

\begin{abstract}
Abstrak
Minyak bumi adalah salah satu bahan bakar fosil dan bahan kimia yang termasuk dalam bahan berbahaya dan beracun, sehingga memerlukan penanganan khusus dalam penanganan perminyakan di lapangan "X". Gathering Station Center adalah salah satu stasiun pengumpul yang mengumpulkan dan merawat minyak dari sumur, dimana menghasilkan air limbah kemudian diproses di Instalasi Pengolahan Air (IPAL) sebelum dibuang ke lingkungan. Tujuan penelitian ini adalah memahami instalasi pengolahan air limbah dan meneliti konsentrasi polutan inlet dan outlet di IPAL. Metode yang digunakan adalah analisis survei dan analisis, parameter yang digunakan secara keseluruhan adalah Suhu, pH, BOD, COD, Minyak, Sulfida (sebagai $\mathrm{H}_{2} \mathrm{~S}$ ), dan amonia (sebagai $\mathrm{NH}_{3}-\mathrm{N}$ ). Semuanya didasarkan pada PerMenLH No. 4 Tahun 2007 tentang ambang air limbah untuk industri minyak, gas, dan panas bumi.

Minyak yang mengalir dilapangan "X" dengan menggunakan flowline kemudian diakhiri dengan choke manifold kemudian dialirkan ke pemisah untuk memisahkan berdasarkan pengendapan gravitasi. Scrubber digunakan untuk memastikan bahwa minyak dan gas telah betul-betul terpisah dari air. Air ini kemudian diinjeksikan kedalam sumur untuk pressure maintenaince, atau jika memenuhi syarat dialirkan ke sungai. Dari semua parameter, air limbah tersebut aman untuk lingkungan karena masih memenuhi syarat dalam PerMenLH No. 4 Tahun 2007.
\end{abstract}

Kata Kunci: Pengelolaan, Proses Instalasi Pengolahan Air Limbah, Minyak dan Gas Bumi.

\begin{abstract}
Abstrack
Petroleum is one of fossil fuel and chemical materials included in dangerous and poisonous materials, thus it needs special treatment in handling petroleum. "X" Gathering Station Center is one of gathering station owned that gathers and treats petroleum from wells where it yields wastewater then processed at Water Treatment Instalation (IPAL) before it is thrown into environment. Goals of this research are understanding wastewater treatment instalation and researching pollutant concentration of inlet and outlet in IPAL. Methods used are survey andlaboratorium analysis, parameters used overall are Temperature, pH, BOD, COD, Oil, sulfide (as $\mathrm{H}_{2} \mathrm{~S}$ ), and ammonia (as $\mathrm{NH}_{3}-\mathrm{N}$ ). Everything is based on PerMenLH No. 4 Year 2007 about wastewater threshold for oil, gas, and geothermal industries.

Petroleum from wells is flown into " $\mathrm{X}$ " by using flowline then ended in choke Manifold. Petroleum is then flown into separator to separate based on gravity settling. Scrubber is used to ensure that oil and gas has succesfully dissapear from thrown to river. From all parameters, wastewater is safe for environment because still reaquires PerMenLH No. 4 Year 2007.
\end{abstract}

Key Words : Management, Process Wastewater Treatment Instalation, Oil and Gas. 


\section{PENGELOLAAN DAN PROSES INSTALASI PERAWATAN AIR LIMBAH DALAM PEMBERSIHAN MINYAK DAN GAS DENGAN MENGGUNAKAN SEPARATOR DAN SCRUBBER DI LAPANGAN "X"}

\section{Pendahuluan}

Kegiatan eksploitasi migas merupakan kegiatan yang memerlukan perhatian yang lebih besar dibandingkan kegiatan lain. Kegiatan tersebut mengandung risiko yang besar baik dari segi biaya maupun keselamatan kerja. Sumber Daya Manusia (SDM) yang handal dan peralatan yang memadai menjadi syarat mutlak agar kegiatan tersebut berjalan dengan lancar. Lancarnya proses eksploitasi tidak lepas dari kegiatan pengontrolan secara berkala untuk mengetahui jumlah produksi dan kerusakan yang terjadi serta prosedur yang benar dalam memproduksikan maupun mengirim hasil ke proses lebih lanjut. Oleh karena itu, diperlukan suatu stasiun pengumpul untuk melakukan kegiatan tersebut. Stasiun Pengumpul mempunyai peranan yang sangat penting dalam menjalankan fungsinya di kegiatan eksploitasi migas, untuk itu perlu diketahui secara lebih mendalam mengenai kegiatan pengoperasian dari Stasiun Pengumpul tersebut.

Dalam proses eksploitasi migas, dampak lingkungan yang dapat dihasilkan dapat cukup serius. Eksploitasi migas akan menghasilkan limbah-limbah yang dapat mencemari lingkungan, khususnya air tanah. Pada proses pengumpulan dan pengolahan hidrokarbon, terdapat fasa cair berupa air yang dihasilkan. Limbah ini masih mengandung beberapa komponen yang dapat mencemari lingkungan jika langsung dibuang. Air limbah hasil pengolahan perlu diproses sedemikian rupa bersamaan dengan proses pengolahan migas. Gathering Station adalah stasiun awal dimana minyak diolah menggunakan beberapa prosedur dan alat. Penulis akan mengkaji proses dan manajemen instalasi pengolahan limbah air dalam proses pemisahan air dan gas menggunakan Separator dan Scrubber.

\subsection{Stasiun Pengumpul (Gathering Station)}

Gathering Station atau yang biasa kita kenal dengan stasiun pengumpul merupakan suatu tempat terjadinya pemisahan fluida pertama kali setelah fluida diangkat dan dialirkan melalui flow line dari sumur. Besar kecilnya suatu stasiun pengumpul tergantung dari banyaknya sumur produksi yang masuk ke dalam stasiun pengumpul tersebut. Bila jumlah sumur yang diproduksi sedikit maka stasiun pengumpul yang dibangun akan berukuran kecil serta mempunyai peralatan yang bersifat sementara.

Fluida produksi dari sumur-sumur ditransportasikan menuju stasiun pengumpul sehingga umumnya letak stasiun pengumpul berada di tengah-tengah kelompok sumur. Adapun fungsi dari stasiun pengumpul diantaranya :

- Menerima fluida produksi dari sumur-sumur

- Mengatur aliran fluida sumur yang masuk ke Gathering Station.

- Memisahkan fluida produksi menjadi komponen gas, minyak, dan air.

- Menampung sementara fluida produksi dan mengalirkan hasil produksi ke proses lebih lanjut.

Cairan (minyak dan air) yang dipisahkan di separator di tampung sementara di tanki. Untuk sumur yang sedang diuji cairannya di tampung di tanki uji dan untuk sumur-sumur campur cairannya ditampung di tanki campur. Di dalam tanki cairan akan diukur dan dicatat. Tanki-tanki yang sudah atau hampir penuh, cairannya dipompa ke Stasiun Pengumpul Utama (SPU).

- Melakukan pengujian atau tes produksi sumur.

Melakukan uji produksi tiap sumur sangat penting untuk mengetahui produksi setiap sumur. Dengan mengetahui produksi tiap sumur dapat diketahui keadaan sumur tersebut apakah hidup, mati, berproduksi besar (gain), berproduksi kecil (low) atau perlu dirawat. Dengan data yang didapat dari tes sumur maka dapat dilakukan program perencanaan perawatan terhadap sumur tersebut.

- Mengetahui produksi harian yang masuk ke Gathering Station tersebut.

Bila di suatu lapangan terdapat banyak Stasiun Pengumpul dan terdapat penurunan produksi, maka akan lebih mudah mengetahui dari kelompok sumur-sumur yang mana penurunan tersebut terjadi bila diketahui produksi harian tiap stasiun pengumpul di daerah tersebut. Dengan demikian pengontrolan terhadap produksi turun lebih mudah dilaksanakan dan lebih cepat dilaksanakan dan lebih cepat diadakan pemeriksaan sumur. Jadi kemerosotan produksi dengan cepat dapat diatasi.

- Mengirim hasil produksi ke Stasiun Pengumpul Utama.

- Mengeringkan gas.

Gas yang keluar dari separator masih sedikit basah. Gas basah tidak saja menurunkan nilai kalori tetapi juga membuat kotor peralatan bahkan seringkali dapat 
membuntu aliran. Untuk mengatasi masalah tersebut gas perlu dikeringkan terlebih dahulu sebelum meninggalkan Stasiun Pengumpul, yaitu dengan menggunakan bejana pengering gas atau gas scrubber.

\subsection{Scrubber}

Scrubber adalah alat yang digunakan untuk memisahkan gas dari cairan yang terikut, tetapi tidak hanya cairan yang terikut saja yang dipisahkan melainkan memisahkan uap fluida yang masih terikut masuk ke scrubber. Scrubber digunakan untuk meyakinkan bahwa gas tidak mengandung material atau fluida yang dapat merusak peralatan compressor.

Adapun penempatan gas scrubber dipasang pada pipa gas setelah separator. Dari scrubber gas selanjutnya gas akan dialirkan menuju tempat yang membutuhkan atau dibakarkan di flare. Gas scrubber ini biasanyaberupa tabung tegak, tetapi ada juga yang berbentuk horizontal, yang hanya digunakan untuk tujuan tertentu.

\subsection{Free Water Knock Out (FWKO)}

FWKO digunakan untuk memisahkan air dan minyak dari fluida hidrokarbon. Air dan minyak dipisahkan dengan gaya gravitasi serta tekanan kurng lebih 39 psi. Air menuju ke bagian bawah FWKO sedangkan minyak menuju bagian atas FWKO. Air kemudian tersekat di bagian bawah yang kemudian dikeluarkan ke Skimming Pit. Sedangkan minyak keluar melalui flowline menuju ke dalam heater treater.

\subsection{Separator}

Separator adalah suatu bejana bertekanan dan bertemperatur tertentu yang digunakan untuk memisahkan dan mengelompokkan fluida produksi menjadi masing-masing fasanya. Separator dapat berfungsi untuk:

- Untuk memisahkan fluida produksi menjadi komponen gas dan cairan. Jenis ini desebut separator dua fasa.

- Untuk memisahkan fluida produksi menjadi fasa gas, air dan minyak. Separator jenis ini disebut separator tiga fasa.

Separator-separator dipasang setelah manifold header dan sebelum tanki-tanki penampung minyak. Bila terdapat lebih dari satu jenis tekanan kerja yang dioperasikan maka susunan tempatnya adalah sebagai berikut:

- Deret depan atau deret pertama adalah kelompok separator tekanan tinggi

- Deret tengah atau kedua adalah kelompok separator tekanan menengah

- Deret belakang atau deret ketiga adalah kelompok separator tekanan

Bila memberi penomoran pada separator hendaknya dilakukan dari separator paling depan diteruskan ke belakang. Berdasarkan bentuknya separator dapat dibedakan menjadi tiga jenis yaitu:

- Separator tegak

- Separator datar

- Separator bundar

Berdasarkan fasa pemisahannya separator dapat dibedakan menjadi dua macam yaitu:

- Separator Dua Fasa (Two Phase Separator)

Separator dua fasa ini memisahkan fluida sumur menjadi komponen gas dan komponen cairan yaitu minyak dan air masih menjadi satu. Gas akan dikeluarkan dan dialirkan menuju bejana Pengering Gas (Gas Scrubber), sedangkan cairannya akan dikeluarkan dan dialirkan ke tanki penampung.

- Separator Tiga Fasa (Three Phase Separator)

Separator tiga fasa digunakan untuk memisahkan fluida sumur menjadi tiga komponen yang terpisah, yaitu gas, minyak dan air. Masing-masing komponen tersebut dialirkan melalui pipa tersendiri. Gas akan dialirkan menuju Gas Scrubber, minyak dialirkan menuju tanki timbun dan air dialirkan menuju oil catcher atau ditampung di tanki kemudian diinjeksikan ke dalam sumur.

\section{Metodologi}

Metode penelitian dan pengumpulan data yang digunakan untuk memperoleh data-data atau informasi yang dibutuhkan, yaitu :

\section{a. Studi Literatur}

Studi literatur untuk mendapatkan data data atau informasi yang mendukung penelitian dari buku-buku penunjang, jurnal, serta referensi lainnya yang terkait. 
PENGELOLAAN DAN PROSES INSTALASI PERAWATAN AIR LIMBAH DALAM PEMBERSIHAN

MINYAK DAN GAS DENGAN MENGGUNAKAN SEPARATOR DAN SCRUBBER DI LAPANGAN "X"

b. Observasi Lapangan

Mengadakan kunjungan langsung pada obyek yang akan diamati.

c. Eksperimen Laboratorium

Melakukan pengujian sampel air limbah hasil pengolahan yang diambil pada inlet dan outlet.

\section{Hasil dan Pembahasan}

Lapangan "X" termasuk salah satu lapangan minyak yang terdapat di wilayah Distrik I. Lapangan "X" memiliki 6 SP, 1 SS dan 1 SPU, salah satunya adalah SP IV "X". SP IV "X" merupakan suatu tempat untuk melakukan proses pemisahan fluida setelah fluida keluar dari sumur. Adapun jumlah sumur yang masuk ke SP IV adalah 7 sumur. Dengan rincian sebagai berikut: Sumur Kw 18, Kw 80, Kw 94, Kw 16, Kw 61, Kw 98 dan Kw 79 yang diproduksi dengan metoda pengangkatan Sucker Rod Pump (SRP).

Fluida dari sumur-sumur tersebut akan masuk ke SP IV melalui fllowline dengan diameter pipa 3" untuk dilakukan pemrosesan. Pipa dari semua sumur akan bertemu menjadi satu di dalam manifold dan akan diarahkan oleh header menuju ke separator tes/uji untuk sumur yang akan dites produksinya dan ke separator campur/grup untuk sumur yang tidak dites. Di dalam separator fluida akan dipisahkan menjadi fasa gas dan fasa cair karena separator yang digunakan adalah separator jenis dua fasa. Setelah dari separator, cairan akan dialirkan masuk ke dalam tanki grup atau menuju ke tanki tes untuk sumur yang sedang dites sedangkan untuk gas dialirkan menuju gas scrubber untuk dipisahkan gas dari kabut-kabut air yang terikut.

Tanki di SP IV "X" berjumlah 8 tanki, 6 tanki berkapasitas $28 \mathrm{~m}^{3}$ sedangkan 2 tanki berkapasitas $20 \mathrm{~m}^{3}$. Adapun tanki tes yang berjumlah 6 buah dan tanki group berjumlah 2 buah. Di tanki-tanki tersebut terjadi proses pemisahan fluida dengan cara settling (pengendapan). Cairan (Minyak dan air) tersebut akan dikirim ke SPU melalui trunk linedengan diameter 6" dengan cara gravitasi, dan disediakan pula 1 unit pompa sentrifugal merk Harisburg yang berfungsi sebagai pompa transfer untuk membantu apabila cairan sudah tidak bisa dikirim dengan cara gravitasi. Sedangkan gas yang telah dibersihkan akan digunakan untuk bermacammacam keperluan, seperti bahan bakar gas engine sebagai penggerak pompa dan genset (pembangkit listrik) dan untuk perumahan Pertamina.

Stasiun Pengumpul mempunyai beberapa fungsi yaitu mengatur, memisahkan dan menampung fluida sumur serta melakukan tes sumur dan pengeringan gas. SP IV lapangan " $X$ " untuk mendukung fungsinya memiliki peralatan dan fasilitas yang memadai yaitu:

- Manifold dan Header

- Separator

- Gas Scrubber

- Tanki Minyak

- Oil Catcher

- Peralatan Pengaman

- Rumah Jaga

\section{a. Manifold dan Header}

Manifold dan header adalah kumpulan valve-valve dan fitting yang berfungsi untuk mengumpulkan dan menjuruskan aliran sesuai dengan keperluan. SP IV lapangan " $\mathrm{X}$ " memiliki dua jenis manifold yaitu manifold fluida dari sumur -sumur dan manifold gas dari outlet gas separator ditunjukkan pada Gambar 1.

Manifold dan header di SP IV lapangan " $\mathrm{X}$ " tidak dibedakan menurut tekanannya karena semua-sumur yang masuk ke dalam SP IV tersebut memiliki tekanan hampir sama yaitu \pm 3 ksc. Semua sumur tersebut akan masuk ke dalam jenis separator tekanan rendah. Sedangkan untuk manifold gas dari outlet gas separator memiliki dua header yang menuju ke gas scrubber. 


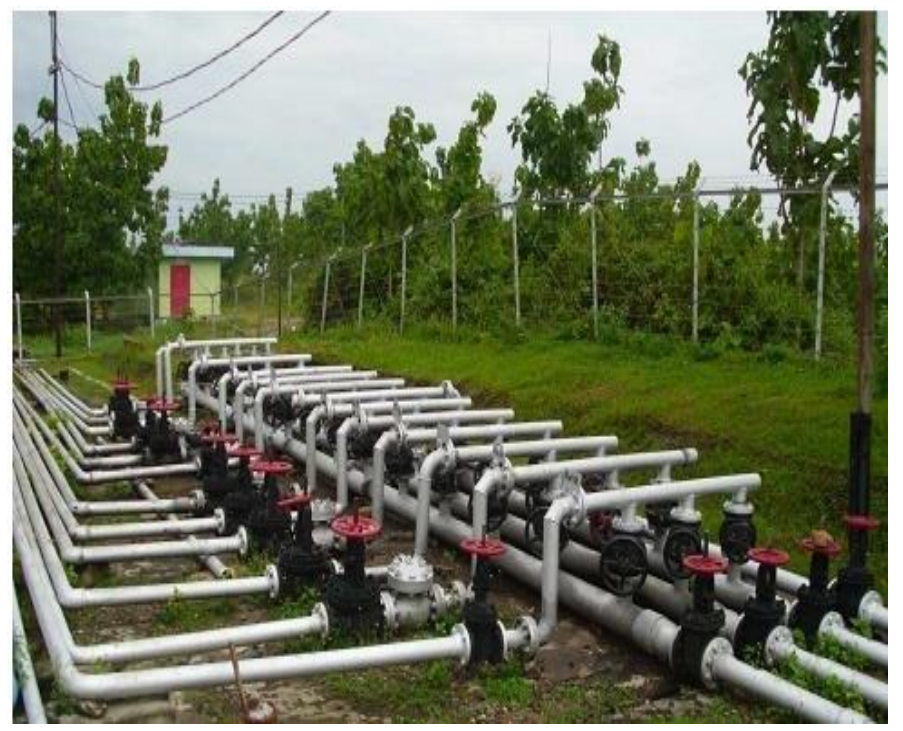

Gambar 1. Manifold dan Header SP IV "X"

\section{b. Separator}

Separator adalah suatu bejana bertekanan dan bertemperatur tertentu yang digunakan untuk memisahkan fluida produksi menjadi masing-masing fasanya. Untuk memisahkan cairan dengan gas digunakan jenis separator dua fasa, sedangkan separator tiga fasa adalah untuk memisahkan fluida produksi menjadi fasa gas, air dan minyak. Di SP IV lapangan "X" memiliki empat unit separator yaitu tiga unit separator tes dan satu unit separator campur atau grup ditunjukkan pada Gambar 2 Separator yang digunakan di SP IV lapangan " $X$ " merupakan separator tegak (vertical separator) peninggalan zaman Belanda, sehingga separator tersebut tidak di bedakan menurut tekanannya. Separator-separator tersebut adalah separator dua fasa yang berfungsi untuk memisahkan fluida menjadi gas dan cairan.

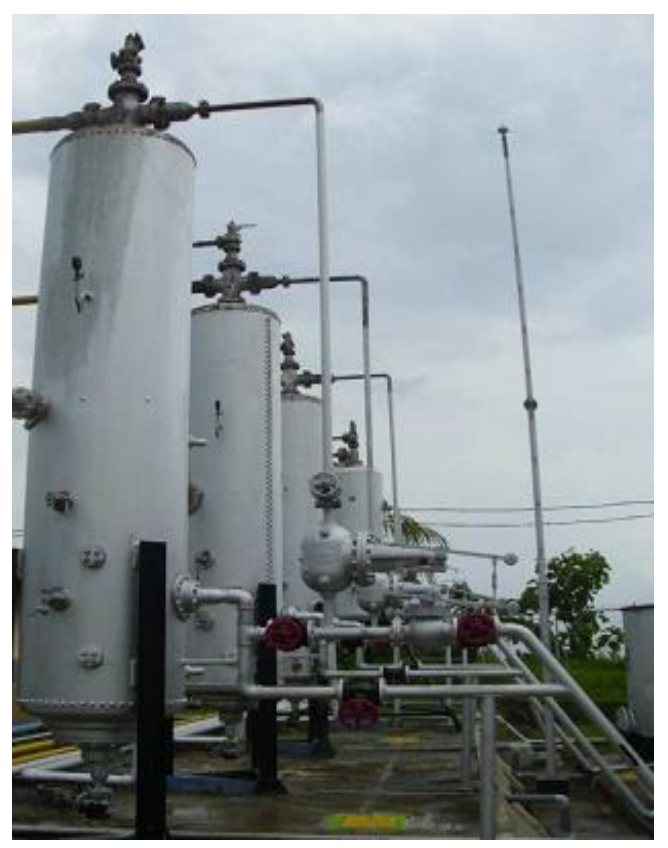

Gambar 2. Separator SP IV lapangan "X"

\section{c. Gas Scrubber}

Gas scrubber adalah sebuah bejana bertekanan yang bentuknya seperti separator yang dirancang untuk memisahkan gas dari partikel air yang terkondensasi setelah pemisahan awal. Gas scrubber yang ada di SP IV lapangan "X" hanya satu unit berbentuk tegak atau vertical ditujukkan pada Gambar 3. Gas scrubber tersebut ditempatkan satu deret dengan separator. Sampai saat ini scrubber tersebut masih di gunakan untuk 
PENGELOLAAN DAN PROSES INSTALASI PERAWATAN AIR LIMBAH DALAM PEMBERSIHAN

MINYAK DAN GAS DENGAN MENGGUNAKAN SEPARATOR DAN SCRUBBER DI LAPANGAN "X"

mengeringkan gas yang nantinya digunakan untuk serta dialirkan ke perumahan-perumahan penggerak mesin pompa, mesin power plant

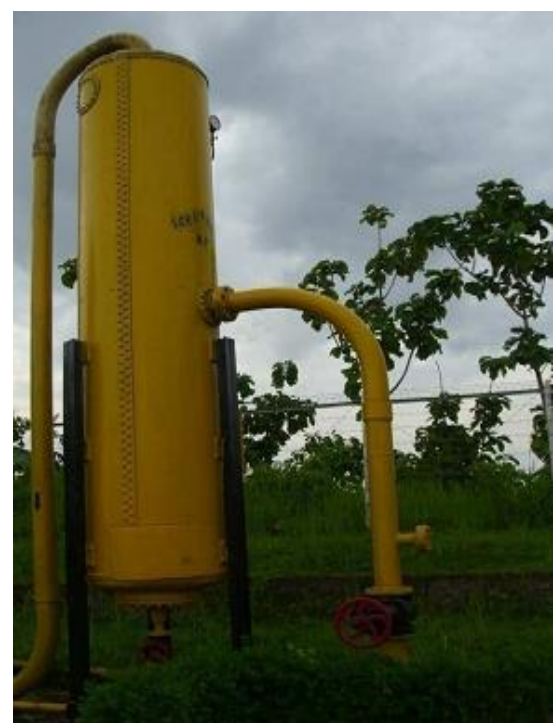

Gambar 3. Gas Scrubber

\section{d. Tanki Minyak}

Tanki-tanki di stasiun pengumpul adalah tanki-tanki atmosferis yang dipergunakan untuk menimbun sementara produksi cairan yang diterima di stasiun pengumpul tersebut. SP IV lapangan "X" memiliki delapan unit tanki dengan rincian satu unit tanki campur atau grup dan tujuh unit tanki tes atau uji ditunjukkan pada Gambar 4. Keseluruhan dari tanki tersebut silindris tegak dan berjenis fixed roof tank dengan bentuk atap cone (kerucut) dan flate (mendatar).

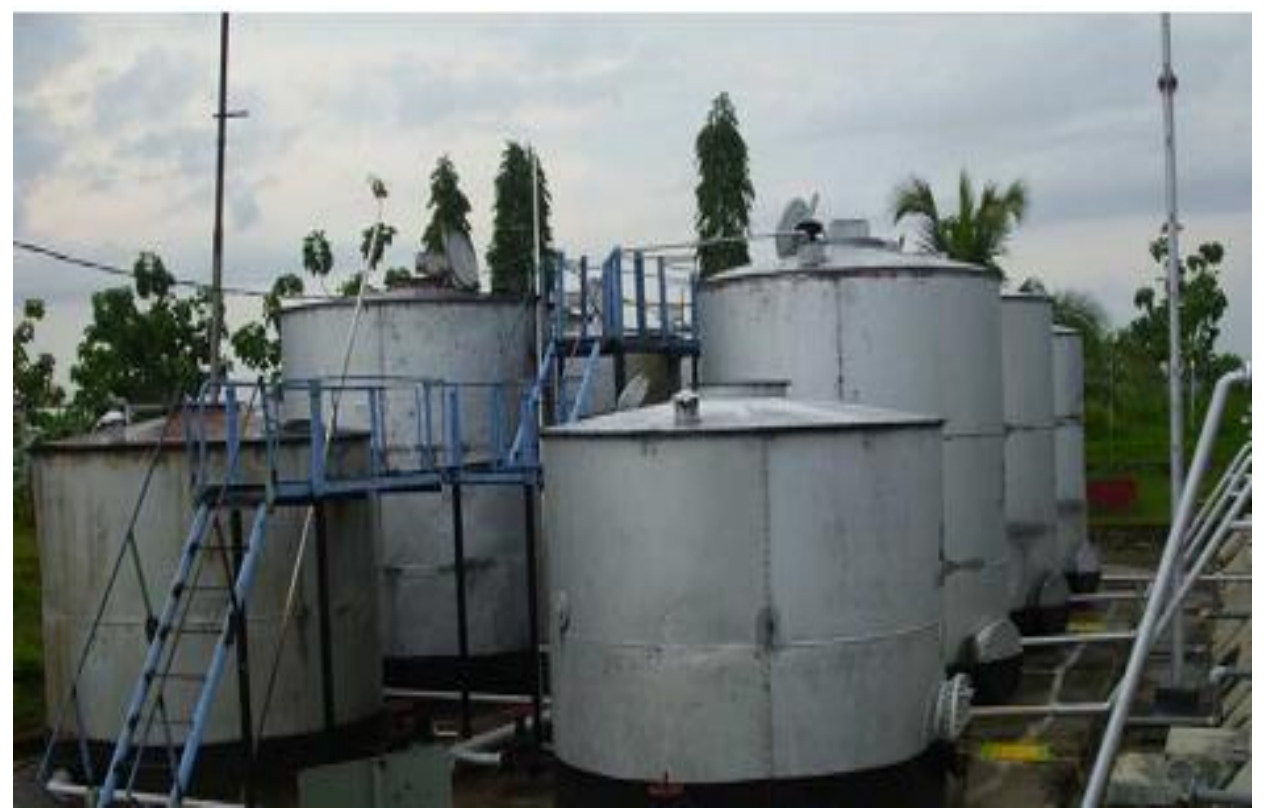

Gambar 4. Tanki Minyak di SP IV lapangan "X"

Tanki tes yang berjumlah tujuh unit digunakan untuk menguji sumur secara bergantian. Pengujian atau tes sumur biasa dilakukan untuk empat sumur per hari dengan durasi empat jam untuk setiap sumurnya. Cairan yang ada di dalam tanki, sebelum dialirkan ke
Stasiun Pengumpul Utama dilakukan pengukuran terlebih dahulu untuk mengetahui produksinya.

Produksi cairan di lapangan sering disebut dengan produksi gross. Pengukuran produksi ini harus dilakukan secermat mungkin agar mendapatkan hasil yang akurat. Untuk pengukuran di SP IV lapangan " $X$ " dilakukan 
dengan metode innage yang menggunakan stick meter sebagai alat pengukur dan pasta (water finder special) sebagai penunjuk adanya air. Adapun SOP (Standar Operating Procedure) untuk pengukuran tinggi cairan di dalam tanki Stasiun Pengumpul IV lapangan " $X$ " sebagai berikut:

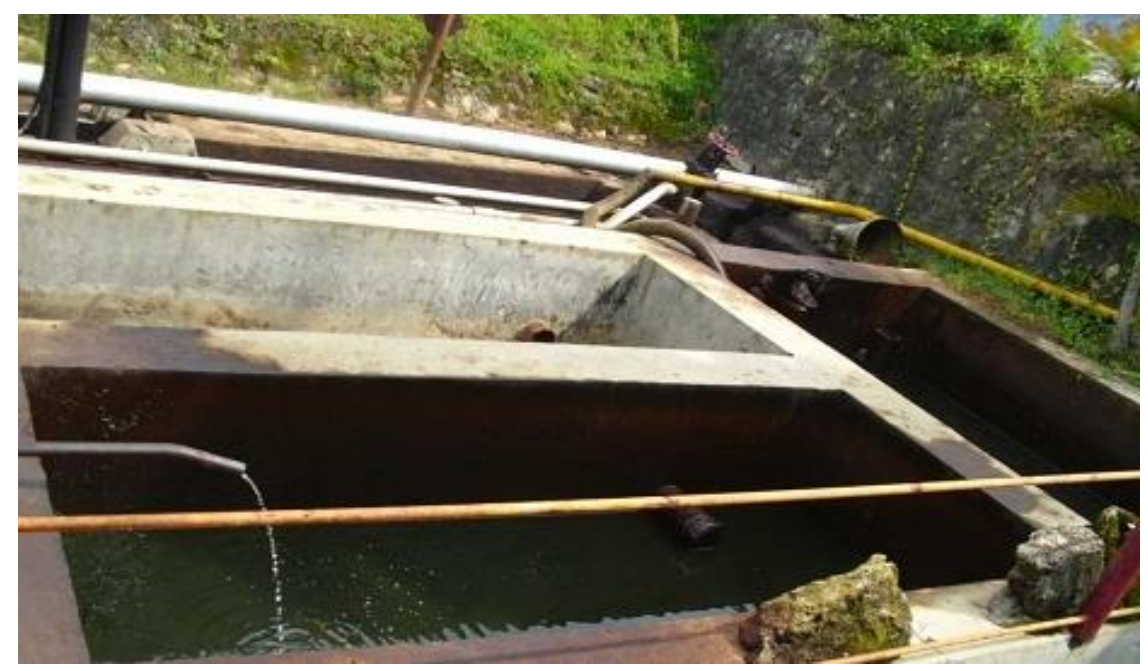

Gambar 5. Oil Catcher SP IV lapangan "X

\section{e. Oil Catcher}

Oil catcher adalah bak persegi panjang yang letaknya ditanah dan di dalamnya bersekatsekat menjadi dua atau tiga sekatan yang bawahnya berlubang untuk menghubungkan antar sekatan yang satu dengan yang lain, dan berfungsi sebagai tempat menangkap tumpahantumpahan minyak pada saat proses penceratan air. Formasi ditunjukkan pada Gambar 5. Minyak yang dibawa oleh air formasi akan terperangkap pada bak pertama yang dibawahnya berlubang untuk saling berhubungan dengan bak yang lain, sedangkan minyaknya terapung yang nantinya akan dipompakan kembali ke tanki penampung.

\section{f. Peralatan Pengaman}

Kecelakaan dan kebakaran adalah sebuah risiko yang bisa terjadi di Stasiun Pengumpul. Untuk itu diperlukan alat-alat penunjang keamanan yang cukup untuk mengatasi hal tersebut. Di SP IV lapangan "X" dilengkapi dengan beberapa peralatan pengaman yang berfungsi untuk menunjang proses pengamanan di tempat itu.

\section{g. Rumah Jaga}

Rumah jaga yang berada di dalam lingkungan Stasiun Pengumpul dilengkapi dengan fasilitas komunikasi dan peralatan penunjang untuk mendukung pekerjaan operator di Stasiun Pengumpul tersebut. Di SP IV lapangan "X" terdapat satu buah rumah jaga yang digunakan oleh operator untuk melakukan pekerjaan pendataan dan pengawasan terhadap peralatan maupun pemrosesan fluida di Stasiun Pengumpul tersebut. Di dalamnya terdapat satu unit pesawat telepon, satu unit televisi dan satu unit papan pengumuman berisi: SOP, flow diagram dan kalibrasi tanki, selain itu juga terdapat peraturan keselamatan kerja yang ditempel di dinding ruangan rumah jaga tersebut.

\section{h. Pengiriman Minyak ke SPU}

Pengiriman minyak dari SP IV lapangan " $X$ " menuju ke SPU dilakukan dengan metode gravitasi. Pengiriman minyak tersebut dilakukan dengan menggunakan trunk line berdiameter 6", dan disediakan pula 1 unit pompa sentrifugal merk Harisburg yang berfungsi sebagai pompa transfer untuk membantu apabila cairan sudah tidak bisa dikirim dengan cara gravitasi. 


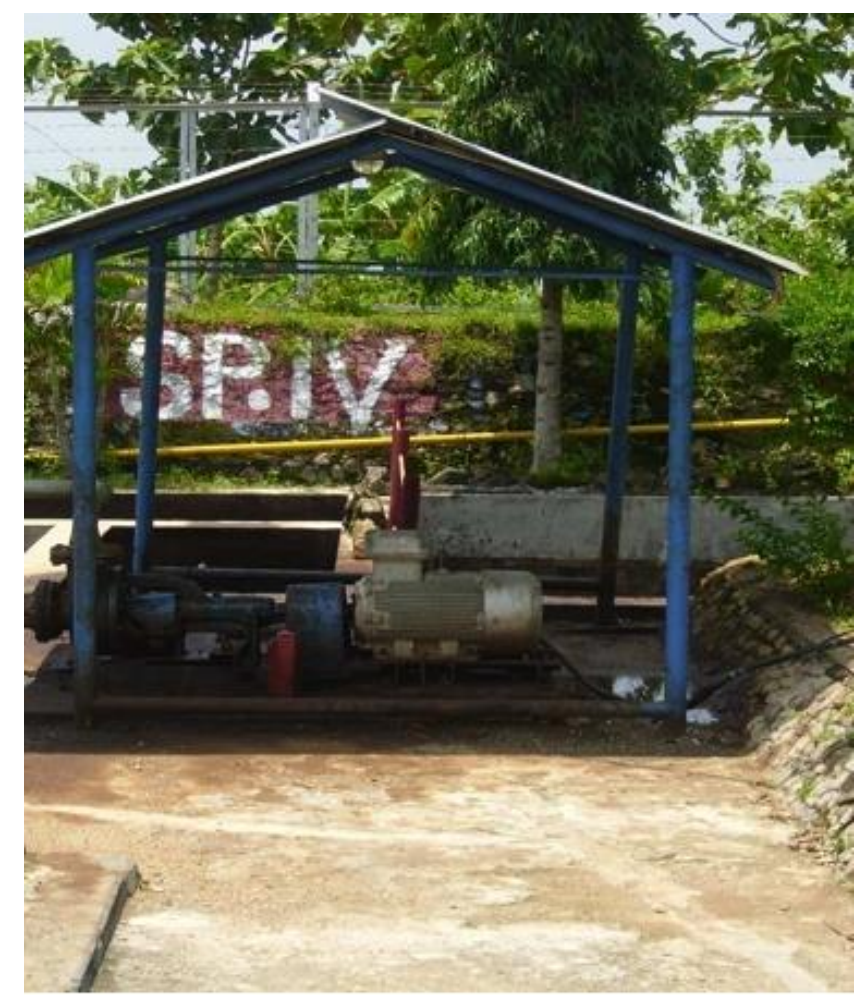

Gambar 6. Pompa Transfer SP IV lapangan "X"

Air yang telah mengalami proses pemisahan dari minyak dan gas inilah yang kemudian disebut sebagai air limbah, karena merupakan fluida sisa dari hasil treatment fluida hidrokarbon. Air limbah yang keluar dari Scrubber kemudian akan dialirkan menuju Tanki Air. Pada periode tertentu kemudian dari tanki akan ada pipa yang diarahkan menuju ke dalam sumur-sumur produksi. Pembuangan fluida keluar dari dalam stasiun " $\mathrm{X}$ " ini menggunakan pompa transfer yang juga sekaligus berfungsi sebagai pompa transfer fluida hidrokarbon ke stasiun selanjutnya, seperti ditunjukkan oleh Gambar 6. Pompa transfer ini akan memompa air limbah menuju ke tempat tertentu seperti misal kembali ke sumur untuk injeksi. Sumur injeksi dalam kasus ini satu bagian dengan sumur produksi. Air limbah ini kemudian akan dijadikan sebagai pressure maintenance atau penjaga kestabilan tekanan. Air limbah yang ada kemudian diinjeksikan ke dalam sumur untuk mengimbangi tekanan bawah sumur (Pwf) datau tekanan formasi jika tekanan tersebut lebih besar dari tekanan kepala sumur (wellhead pressure) maupun tekanan separator.

Pemanfaatan air limbah hasil pengolahan hidrokarbon sebagai pressure maintenance memiliki nilai ekonomis bagi perusahaan karena biaya operasional untuk menjaga sumur tetap beroperasi menjadi kecil dan mengurangi resiko terjadinya kenaikan tekanan yang terlalu besar pada sumur akibat tekanan formasi. Berdasarkan hasil pengujian terhadap parameter-parameter air limbah pada inlet dan outlet dihasilkan sebagai berikut :

Tabel 1. Hasil Pengujian di Inlet

\begin{tabular}{|l|c|c|}
\hline \multicolumn{1}{|c|}{ Parameter } & Hasil & $\begin{array}{c}\text { Memenuhi Syarat } \\
\text { PerMenLH }\end{array}$ \\
\hline Temperatur & 78 derajat C & Tidak \\
\hline $\mathrm{pH}$ & 3,5 & Tidak \\
\hline BOD & $95 \mathrm{mg} / \mathrm{L}$ & Tidak \\
\hline COD & $187 \mathrm{mg} / \mathrm{L}$ & Tidak \\
\hline Kandungan Minyak & $36 \mathrm{mg} / \mathrm{L}$ & Tidak \\
\hline Kandungan Gas H2S & $2,4 \mathrm{mg} / \mathrm{L}$ & Tidak \\
\hline Kandungan Ammonia & 14 & Tidak \\
\hline
\end{tabular}


Tabel. 2. Hasil Pengujian di Outlet

\begin{tabular}{|l|c|c|}
\hline \multicolumn{1}{|c|}{ Parameter } & Hasil & \multicolumn{1}{c|}{$\begin{array}{c}\text { Memenuhi Syarat } \\
\text { PerMenLH }\end{array}$} \\
\hline Temperatur & 39 derajat C & Memenuhi \\
\hline pH & 6,2 & Memenuhi \\
\hline BOD & $54 \mathrm{mg} / \mathrm{L}$ & Memenuhi \\
\hline COD & $158 \mathrm{mg} / \mathrm{L}$ & Memenuhi \\
\hline Kandungan Minyak & $12 \mathrm{mg} / \mathrm{L}$ & Memenuhi \\
\hline Kandungan Gas H2S & $0,3 \mathrm{mg} / \mathrm{L}$ & Memenuhi \\
\hline Kandungan Ammonia & 7 & Memenuhi \\
\hline
\end{tabular}

\section{Kesimpulan}

Migas dari sumur-sumur dialirkan menuju SP lapangan " $\mathrm{X}$ " menggunakan flowline dan berakhir di choke manifold. Migas kemudian dimasukkan ke separator untuk dipisahkan dengan prinsip gravitasi. Scrubber digunakan untuk memastikan bahwa minyak dan gas telah betulbetul terpisah dari air. Air ini kemudian diinjeksikan kedalam sumur untuk pressure maintenaince, atau jika memenuhi syarat dialirkan ke sungai. Dari semua parameter, air limbah tersebut aman untuk lingkungan karena masih memenuhi syarat dalam PerMenLH No. 4 Tahun 2007.

\section{Ucapan Terima Kasih}

Penulis sangat mengucapkan terima kasih pada PT. Geo Cepu Indonesia KSO PT. Pertamina Asset IV Cepu dan Laboratorium Terpadu Jurusan Teknik Lingkungan Institut Teknologi Yogyakarta.

\section{Daftar Pustaka}

Arnold, Ken and Maurice Steward, 1986, "Surface Production Operation", Volume I, Houston: Gulf Publishing Company.

Chilingar, George V. Dan Carrol M. Beeson, 1969, "Surface Operation in Petroleum Production", New York: American Elsevier Publishing Company.

Nurhendro, Kunto, Ir., M.M., 2011,'Teknik Eksploitasi", bahan kuliah, Cepu: Akamigas-STEM.

Untoro, Edy, 2006,"Diktat Teknik Produksi" Cepu: Akamigas-STEM.

Data / Dokumentasi dari PT. Geo Cepu Indonesia KSO PT. Pertamina Aset IV Cepu, 2017 